\title{
WATER RESOURCES MANAGEMENT IN URBAN AREAS - A SUSTAINABLE SOLUTION THROUGH IBWT
}

\author{
G A Rajkumar', M K Srinivas ${ }^{2}$, L R Ranganath ${ }^{3}$, M D Kudale ${ }^{4}$ \\ ${ }^{1}$ Assistant Research Officer, Central Water \& Power Research Station, Pune, ga_rajkumar@hotmail.com \\ ${ }^{2}$ Chief Engineer (South), National Water Development Agency, Hyderabad, srinivasmk@rediffmail.com \\ ${ }^{3}$ Scientist 'D, Central Water \& Power Research Station, Pune, praranga@yahoo.com \\ ${ }^{4}$ Scientist É, Central Water \& Power Research Station, Pune, kudale_md@cwprs.gov.in
}

\begin{abstract}
Rapid urban growth threatens sustainable development when the basic pre-requisites such as sustainable and efficient domestic water supply in urban areas are not ensured. Rapid urbanization demands for a sustainable and efficient Water Resources Management for the urban areas. The availability of water is scarce with steady increase in demand of water owing to increasing population, rapid urbanization, etc. and hence there is an immense necessity to augment water availability for domestic utilization. The National Water Policy of Government of India (GOI) revised in 2012 accords over-riding priority to drinking water over other uses. National Water Policy also emphasizes the need for Inter Basin Water Transfer (IBWT) while assigning highest priority for drinking water supply needs followed by other uses. As per the census of India - 2011, the Greater Mumbai with a population of 184.14 lakhs continues to be India's biggest city. The initial estimates of Municipal Corporation of Greater Mumbai (MCGM) indicate a gross shortage of about $1053 \mathrm{Mm}^{3}$ of water for the domestic requirements of Mumbai. Preliminary water balance studies carried out by National Water Development Agency (NWDA) revealed that surplus waters are available in the Damanganga basin which can be transferred for supplementing the domestic water requirements of Greater Mumbai. Detailed Project Report of D-P link project prepared by NWDA envisages construction of two dams viz., one across river Damanganga near Bhugad village and another at Khargihill across river Vagh (a tributary of Damanganga) along with two tunnels connecting Bhugad, Khargihill \& Pinjal reservoirs. Based on studies it has been ascertained that about $210 M m^{3}$ water from Bhugad reservoir and about $369 \mathrm{Mm}^{3}$ of water from Khargihill reservoir (total $579 \mathrm{Mm}^{3}$ from Damanganga basin), can be transferred to Pinjal reservoir. Thus the combined surplus waters of Bhugad and Khargihill reservoirs of Damanganga basin to the extent of $579 \mathrm{Mm}^{3}$ along with surplus waters available at Pinjal reservoir of Vaitarna basin (316 $\left.\mathrm{Mm}^{3}\right)$ totalling to about 895 $\mathrm{Mm}^{3}$ can be transferred through D-P link to Mumbai city for augmenting its domestic needs. The combined surplus waters of Damanganga and Pinjal rivers will be taken further to Mumbai city as per the planning of MCGM and Mumbai Metropolitan Regional Development Authority (MMRDA). In view of the acute scarcity \& stressed water conditions prevalent owing to rapid increase in population and depletion of natural water resources in urban areas, the augmentation of domestic water needs in urban areas can be tackled effectively through IBWT.
\end{abstract}

Keywords: Urbanization, National Water Policy, Inter Basin Water Transfer, Dams

\section{INTRODUCTION}

As per the census of India - 2011, the population has increased from 102.9 crores (2001 census) to 121.0 crore, while the level of urbanization has increased from $27.81 \%$ (2001 Census) to $31.16 \%$ (2011 Census Further as per the 2011 census report, the rural population figures stand at 83.3 crores and 74.3 crores while the urban population figures stand at 37.7 crores and 28.6 crores as per the 2011 and 2001 census respectively). The Greater Mumbai with a population of 184.14 lakhs continues to be India's biggest city.

As per the recent report of the Department of Economic and Social Affairs of United Nations - 2014, worldwide, urban population is more than rural population, with 54 per cent of the world's population residing in urban areas in 2014. In 1950,30 per cent of the world's population was urban while by 2050,66 per cent of the World's population is projected to be urban. The global rural population is now close to 3.4 billion and is expected to decline to 3.2 billion by 2050 .

Continuing population growth and urbanization are projected to add 2.5 billion people to the world's urban population by 2050 . India is expected to add 404 million urban dwellers.

The increase in urbanization can primarily be attributed to rural-urban migration, extension of existing areas as 'Urban' $\&$ to a natural increase. The tendency of steady upward revision levels in urbanization could be seen as an indicator of economic development supplementing the progress of the country. Rapid urban growth threatens sustainable development when the basic pre-requisites such as sustainable and efficient domestic water supply in urban areas are not ensured. Rapid urbanization demands for a sustainable and efficient of Water Resources Management for the urban areas. 


\subsection{WATER RESOURCES OF INDIA}

\subsection{Rivers \& Rainfall}

The river system of India can be classified into two groups, viz., the perennial rivers of the Himalayan region and rivers of peninsular India. In the peninsula, the flow is significant with heavy discharges during the monsoons followed by low discharges during the non monsoon months. In the Himalayan river system, the dry weather flow is significantly enhanced by water from the melting snows and glaciers while the lean period for these rivers is the winter. The rivers fed from Glaciers and snowmelts are often uncertain and unpredictable in their behaviour while relatively the peninsular rivers are more predictable in their behaviour.

India experiences a great regional and temporal variation in the distribution of rainfall. It has an annual average precipitation of $1170 \mathrm{~mm}$ and about $80 \%$ of total area of the country experiences annual rainfall of $750 \mathrm{~mm}$ or more. The summer or south-west monsoon and winter or the north-east monsoons bring rain to Indian peninsula. But the greater part (as much as $90 \%$ ) of annual rainfall is received between June and October, the period of the south-west monsoons, which consists of two distinct currents of wind, one coming from the Bay of Bengal and other from the Arabian Sea. The rainfall is highly variable with asymmetrical seasonal \& geographical distribution.

\subsection{Availability of Water Resources}

Out of the total annual precipitation of 4000 BCM the rainfall during monsoon months (June-September) is of the order of $3000 \mathrm{BCM}$. There are also very large temporal and spatial variations of rainfall during monsoon period. While the average annual rainfall of the country is about $1170 \mathrm{~mm}$, the rainfall varies from $100 \mathrm{~mm}$ in the western parts of Rajasthan to $10000 \mathrm{~mm}$ at Cherrapunji in Meghalaya. Water Resources potential of the country was assessed by CWC in the year 1993 as 1869 BCM.

The monsoon accounts for more than 85 percent of annual precipitation. The uncertainty of occurrence of rainfall marked by prolonged dry spells and fluctuations in seasonal and annual rainfall is a serious problem for the country. It is estimated that by $2050,30 \%$ of geographical area and $16 \%$ of population in the country will be under absolute water scarcity condition.

Country is facing the improbability of occurrence of rainfall discernible by prolonged dry spells and fluctuations in seasonal and annual rainfall. While some rivers originating from Himalayan region are with abundant flows other rivers in Peninsular India are struggling to meet at least the inbasin needs. The per capita annual availability of water in Brahmaputra is about 13636 cum as against as low as 298 cum in Sabarmati basin. It has been estimated that one third of India's population is either affected by flood or drought every year. Any situation with less than 1000 cum per capita is considered as water scarcity condition.
Further, Ground water is also one of the most important water resources in India. It is estimated that ground water meets more than $85 \%$ of India's rural domestic water requirements, $50 \%$ of its urban water requirement and more than $50 \%$ of its irrigation requirements. Ground water is the main source of water supply in urban areas for domestic use.

\subsection{EFFECTIVE WATER RESOURCES}

\section{MANAGEMENT}

The long term solution to overcome the mbalances in the water availability in country is to create surface storages and requirement of efficient planning for Inter Basin Water Transfer (IBWT). The concept of inter linking of rivers came into limelight primarily to overcome the imbalances in the natural availability of water in time and space.

National Water Development Agency (NWDA), an autonomous society under the Ministry of Water Resources was set up in 1982, with a mandate to promote optimum utilization of water resources of country. NWDA after carrying out detailed studies assessing the quantum of availability of water resources in various river basins/subbasins of India, on a scientific \& realistic basis, firmed up 30 IBWT proposals viz., 14 under Himalayan component and 16 under Peninsular component. The figure showing the IBWT proposals both under the Himalayan \& Peninsular component is enclosed as Fig.1.

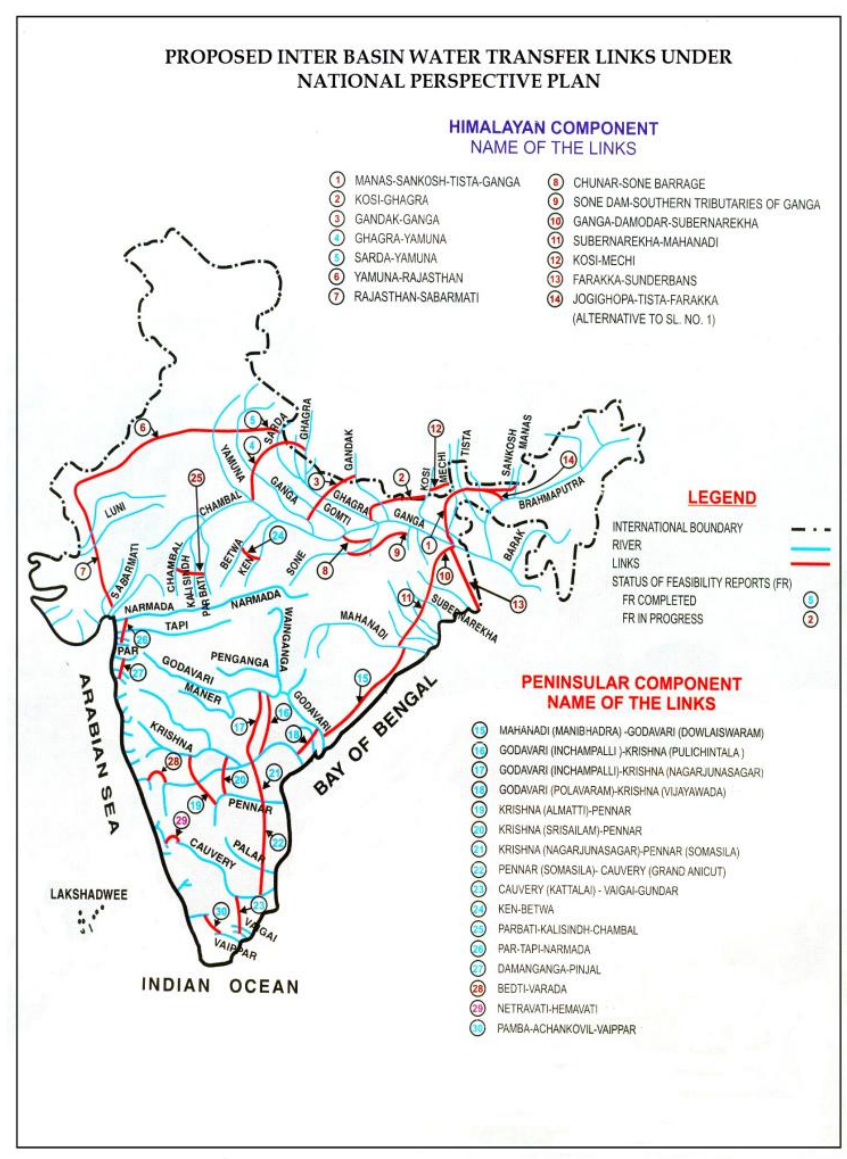

Figure 1. Inter Basin Water Transfer proposals 
Water requirement in the households for drinking, cooking, washing, cleaning etc., needs is not very large as compared to requirements for all uses. The problem is its availability; huge costs involved for its augmentation and the more important its efficient management. The availability of water is scarce with steady increase in demand of water owing to increasing population, rapid urbanization, etc. and hence there is an immense necessity to augment water availability for domestic utilization. Effective, efficient management of water resources is vital for any urban area to sustain.

The National Water Policy 2012 of Government of India (GOI) accords over-riding priority to drinking water over other uses. National Water Policy also emphasizes the need for Inter Basin Water Transfer (IBWT) while assigning highest priority for drinking water supply needs followed by other uses.

\subsection{AUGMENTING DOMESTIC WATER SUPPLY OF MUMBAI CITY THROUGH IBWT - A CASE STUDY}

As per the Census 2011, Greater Mumbai with a population of 184.14 lakhs continues to be India's biggest city. Looking at the trend of development in Greater Mumbai it is predictable that there would be acute shortage of domestic \& industrial water needs by the year 2050. The entire water supply of Mumbai is dependent on a series of dams like Vaitarna, Upper Vaitarna, Tansa and Bhatsa. As per the preliminary assessment of Muncipal Corporation of Greater Mumbai (MCGM), the projected domestic water demand for Greater Mumbai will be $2555 \mathrm{Mm}^{3}$ while the cumulative water supply available from various sources including from middle Vaitarna, Bhatsa and Gargai projects would be 1502 $\mathrm{Mm}^{3}$. Thus, there will be a gross shortage of about 1053 $\mathrm{Mm}^{3}$.

Preliminary water availability studies carried out by NWDA for the west flowing river basins between north of Mumbai and south of the Tapi revealed that surplus waters are available in the Damanganga basin which can be transferred for augmentation of water supply to Greater Mumbai to meet its domestic needs.

The Feasibility Report of Damanganga - Pinjal (D-P) link project was prepared by NWDA during November, 2004 and consensus was arrived amongst the Central Government and beneficiary states viz., Gujarat and Maharashtra for preparation of Detailed Project Report (DPR) of D-P link project.

The DPR of the proposed D-P link project prepared by NWDA envisages construction of a dam across river Damanganga near Bhugad village in Peinttaluka of Nasik district of Maharashtra; a dam at Khargihill across river Vagh (a tributary of Damanganga) near village Behadpada in Mokhada taluka of Thane district of Maharashtra state; a dam across river Pinjal near village Khidse in Wada taluka of Thane district (proposed by Government of Maharashtra) and 2 tunnels connecting Bhugad reservoir with Khargihill reservoir and Khargihill reservoir with Pinjal reservoir. The layout plan of the D-P link project is enclosed as Fig.2. The basic objective of D-P link being augmentation of the domestic water requirements of the Mumbai city as such the project has been planned at $100 \%$ dependability.

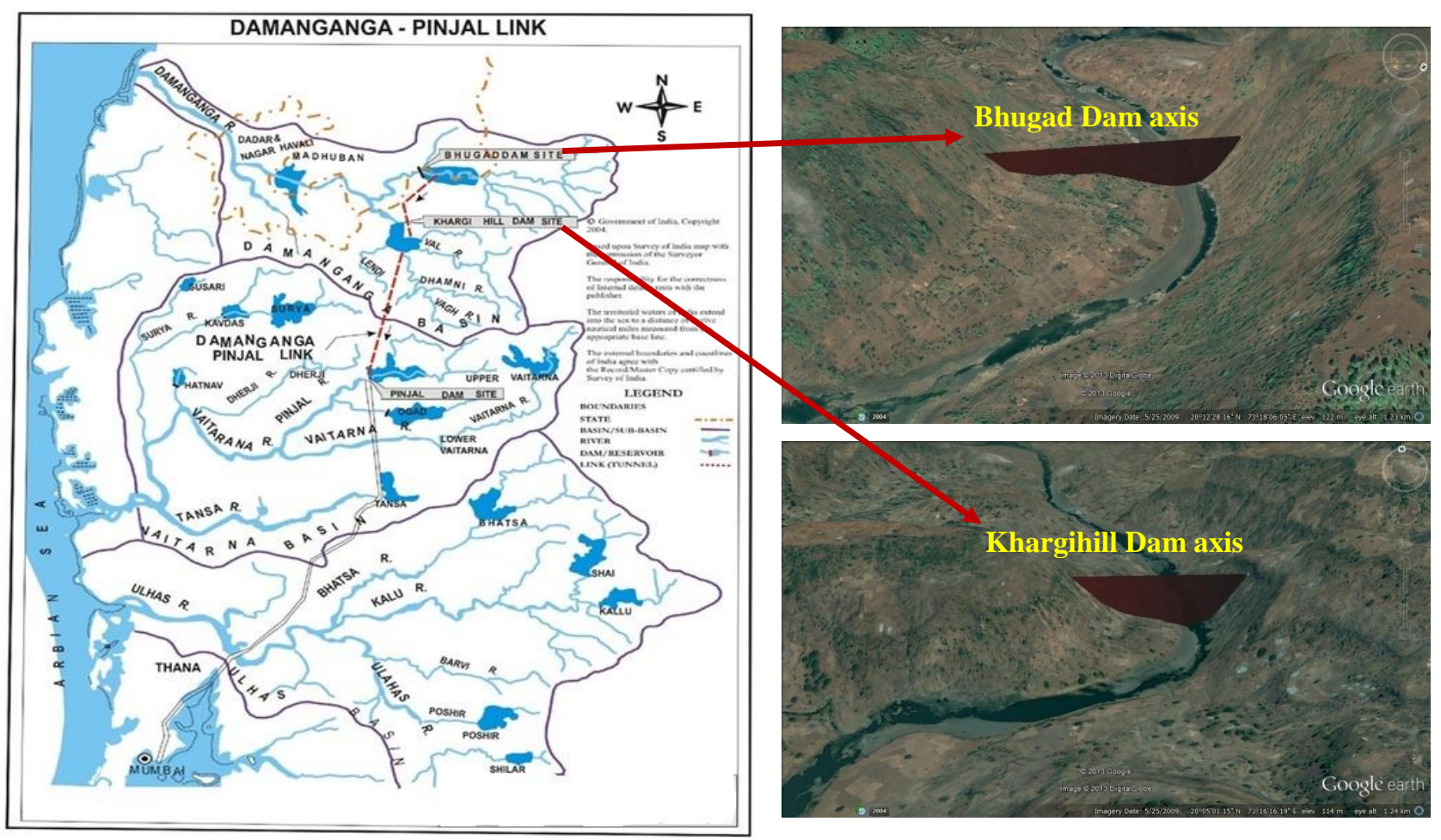

Figure 2. Index Map of Damanganga - Pinjal link project 


\subsection{Water Availability}

Hydrological studies to assess the water balance position at the ultimate stage of development (by the year 2050 AD) in Damanganga basin have been carried out as a whole and also up to the proposed Bhugad and Khargihill dam sites. The 100\% dependable annual gross yields at Bhugad, Khargihill, Pinjal dam sites and for whole Damanganga basin have been assessed as 372 MCM, 477 MCM, 420 MCM and 1839 MCM respectively.

Further, the net water availability at $100 \%$ dependability at the diversion points (Bhugad and Khargihill dams) was assessed after considering all the consumptive upstream utilization planned by states for irrigation, hydropower Reservoir evaporation losses, domestic \& Industrial requirements, down-stream committed releases and return flow is indicated below in Table 1.

Table.1 Net Yield in MCM

\begin{tabular}{|c|c|c|}
\hline & At & At \\
& Bhugad & Khargihill \\
\hline $\begin{array}{c}\text { At } 100 \% \\
\text { dependability }\end{array}$ & 284 & Dam site \\
\hline
\end{tabular}

Thus as seen from the above Table that about $685 \mathrm{Mm}^{3}$ of water $\left(284 \mathrm{Mm}^{3}\right.$ and $401 \mathrm{Mm}^{3}$ available at proposed Bhugad and Khargihill dam sites respectively) at $100 \%$ dependability is available in Damanganga basin at the proposed Bhugad and Khargihill reservoirs for transfer to Pinjal reservoir.

Based on the results of the simulation analysis carried out to assess realistically the quantity that can be diverted from Bhugad and Khargihill reservoirs to Pinjal dam, considering the inflows, local demands and committed down-stream releases it has been ascertained that about $210 \mathrm{Mm}^{3}$ water from Bhugad reservoir and about $369 \mathrm{Mm}^{3}$ of Water from Khargihill reservoir (total $579 \mathrm{Mm}^{3}$ from Damanganga basin) at $100 \%$ success rate, can be transferred to Pinjal reservoir. Thus the combined surplus waters of Bhugad and Khargihill reservoirs of Damanganga basin to the extent of $579 \mathrm{Mm}^{3}$ along with surplus waters available at Pinjal reservoir of Vaitarna basin $\left(316 \mathrm{Mm}^{3}\right)$ totalling to about 895 $\mathrm{Mm}^{3}$ can be transferred through D-P link to Mumbai city for augmenting its domestic needs.

\subsection{Salient Features of D-P Link}

A $851.50 \mathrm{~m}$ long dam across river Damanganga near village Bhugad with FRL $163.87 \mathrm{~m}$ and corresponding gross storage capacity of $427 \mathrm{Mm}^{3}$ with a Power house at the toe of Bhugad dam with 2 units each of $1.0 \mathrm{MW}$ installed capacity each.

A $618.20 \mathrm{~m}$ long dam at Khargihill across river Vagh (a tributary of Damanganga river) near village Behadpada with FRL $154.52 \mathrm{~m}$ with corresponding gross storage capacity of $461 \mathrm{Mm}^{3}$. A saddle dam of $400 \mathrm{~m}$ length and $25.92 \mathrm{~m}$ height with FRL $154.52 \mathrm{~m}$ on the left flank of the reservoir._A Power house at the toe of Khargihill dam with 2 units of $1.5 \mathrm{MW}$ installed capacity.

A tunnel of about $17.488 \mathrm{~km}$ long with $3.2 \mathrm{~m}$ diameter connecting Bhugad reservoir with Khargihill reservoir and a tunnel of about $25.224 \mathrm{~km}$ long with $4.00 \mathrm{~m}$ diameter connecting Khargihill reservoir with Pinjal reservoir.

A $545 \mathrm{~m}$ long dam across river Pinjal (a tributary of Vaitarna river) proposed by Government of Maharashtra near village Khidse with FRL of $141 \mathrm{~m}$ and corresponding gross storage capacity of $418 \mathrm{Mm}^{3}$ and a saddle dam of about $190 \mathrm{~m}$ long and $11.4 \mathrm{~m}$ high on the right flank.

The combined surplus waters of Damanganga and Pinjal rivers will be taken further to Mumbai city as per the planning of Municipal Corporation of Greater Mumbai and Mumbai Metropolitan Regional Development Authority. The Schematic diagram of the entire conveyance system as envisaged in D-P link is enclosed as Fig.3 


\section{SCHEMATIC DIAGRAM OF PROPOSED DAMANGANGA - PINJAL LINK PROJECT}

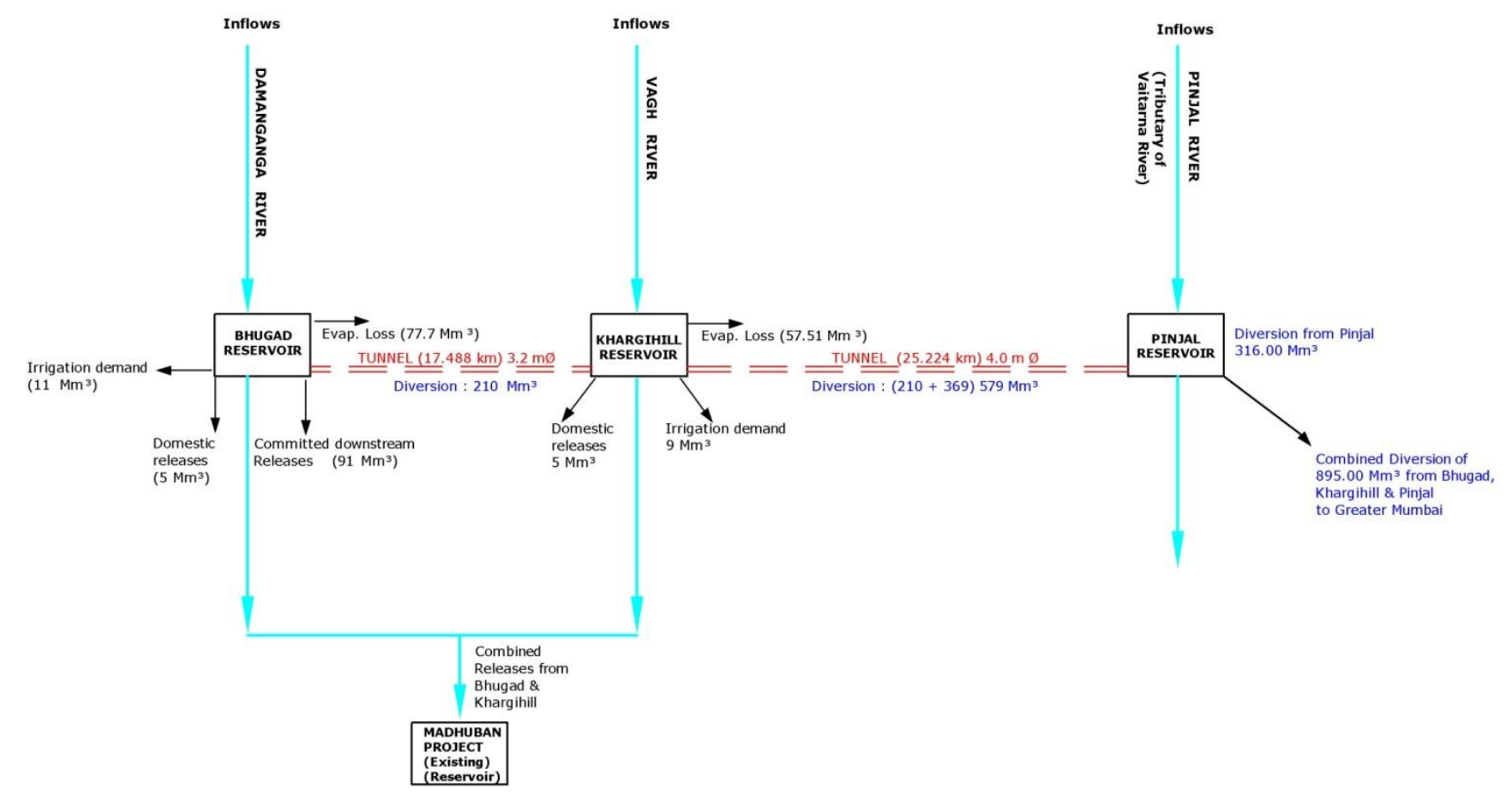

* The quantities indicated above are tentative and are being firmed up at DPR level of studies.

Figure 3. Schematic diagram of proposed Damanganga - Pinjal link project

Following are the advantages and environmental issues due to the proposed D-P link project.

\section{Advantages}

- $\quad$ The D-P link project will facilitate transfer of 895 $\mathrm{Mm}^{3}$ of water for augmentation of domestic water supply to the Mumbai city while meeting the drinking water requirement of the people in the vicinity of the project.

- The water presently flowing into the Arabian sea unutilised can be put into effective use by this diversion for the society.

- The power potential studies indicated feasibility of power houses at both Bhugad and Khargihill dams. Power house at Bhugad dam will be with 2 units of 1.0MW installed capacity each while power house at Khargihill dam will be with 2 units of $1.5 \mathrm{MW}$ installed capacity. Release of water to the link tunnels and creation of reservoirs will also provide incidental benefit of flood moderation in Damanganga river.

- Besides, other indirect benefits such as pisciculture, replenishing of ground water in downstream areas of the proposed dams, development of agro based industries and food processing units due to enhanced water availability, employment generation during and post construction phase, tourism development, development of infrastructure etc. will be accrued from the project.

\section{Environmental Issues}

The Construction of two reservoirs proposed under D-P link will submerge an area of about 3461 ha out of which cultivated land is 1422 ha, forest land is 966 ha and river portion is 1073 ha, affecting about 2302 families. The no. of villages likely to be affected are 30 , all of them are partially affected.

Comprehensive Environment Impact Assessment studies have been carried out primarily to assess the positive and negative impacts of the project on the environment and livelihoods of the people. Based on these studies, detailed Rehabilitation \& Resettlement Package for the project affected people has been devised taking into consideration all related applicable acts and policies. Resettlement 
package inter-alia includes the benefits like compensation for land, house, shop and other property, allotment of homestead land, transportation charges for household items and cattle etc., providing infrastructure facilities in resettlement area, approach roads, electricity, water supply, education, health centers etc., preference in providing employment in project construction, management and monitoring, training facilities etc., participation in catchment area treatment which in turn would benefit local population.

\subsection{CONCLUSION}

Rapid urban growth threatens sustainable development when the basic pre-requisites such as sustainable and efficient domestic water supply in urban areas are not ensured. Rapid urbanization demands for a sustainable and efficient of Water Resources Management. The ground water levels in urban areas are depleting at an alarming rate with the utilization of ground water exceeding the recharge. The roof top rainwater harvesting measures taken up in various cities though augmenting the ground water recharge to some extent, however, are unable to recharge at a rate equal to the drawal of ground water. In view of the acute scarcity \& stressed water conditions prevalent owing to rapid increase in population and depletion of natural water resources in urban areas, the augmentation of domestic water needs in urban areas can be tackled effectively through provision of surface water. As we near the time when water has to be made available at any cost, transfer of surface water through interlinking of rivers appears to be a sustainable solution.

\section{REFERENCES}

[1] Report titled "World Urbanization Prospects-The 2014 Revision" of Department of Economic and Social Affairs, Population Division, United Nations, New York, 2014

[2] Water Resources Development Scenario in India by Central Water Commission, MoWR, RD \& GR.

[3] FR \& DPR Report of Damanganga-Pinjal link project prepared by NWDA.

\section{ACKNOWLEDGEMENT}

The authors wish to thank Shri. S. Govindan, Director, CWPRS for his consistent support, encouragement and kind consent for publishing this paper. 